\title{
Ekstraksi Kolagen Tulang Ikan Tuna (Thunnus sp) Dengan Asam Klorida
}

\author{
Tuhu Edi Suranta Sembiring*, Albert Roike Reo, Hens Onibala, Roike Montolalu, \\ Nurmelita Taher, Feny Mentang, Lena Jeane Damongilala
}

\author{
Program Studi Teknologi Hasil Perikanan, Jurusan Pengolahan Hasil Perikanan, \\ Fakultas Perikanan dan Ilmu Kelautan, Universitas Sam Ratulangi, Manado. \\ *Korespondensi: tuhuedi18@gmail.com \\ (Diterima 24-07-2020; Direvisi 05-08-2020; Dipublikasi 07-08-2020)
}

\begin{abstract}
Previously, commercial collagen are obtained from mammals and poultry. However, there is a huge concern about Bovine Spongiform Encephalopathy (BSE, "mad cow disease") and avian influenza from the consumers, that is why many researcher are trying to explore the utilization of marine animals as source of collagen. The aim of this study is to gathering information about extraction collagen from Tuna (Thunnus sp.) using $1 \%$ and $3 \%$ Chloride Acid. The result indicated that the rendement was $1,42 \%$ and 5,65\%, moisture contents $7 \%$ and $12 \%$, and acidity $(\mathrm{pH}) 4,30 \%$ and $5,19 \%$. These results suggested that the using $3 \%$ chloride acid in the extraction process produced higher collagen.
\end{abstract}

Keywords: Collagen Extraction, Cloride Acid, Tuna Fish.

Sebelumnya, kolagen komersial diperoleh dari mamalia dan unggas. Namun demikian, terdapat kekhawatiran yang sangat besar terhadap Bovine Spongiform Encephalopathy (BSE, "penyakit sapi gila") dan flu burung dari konsumen, oleh karena itu banyak peneliti yang mencoba untuk mengeksplorasi pemanfaatan hewan laut sebagai sumber kolagen. Tujuan dari penelitian ini adalah untuk memperoleh informasi tentang ekstraksi kolagen dari ikan tuna (Thunnus sp.) Menggunakan Asam Klorida 1\% dan 3\%. Hasil penelitian menunjukkan bahwa rendemen $1,42 \%$ dan 5,65\%, kadar air 7\% dan 12\%, serta keasaman (pH) 4,30\% dan 5,19\%. Hasil ini menunjukkan bahwa penggunaan asam klorida $3 \%$ dalam proses ekstraksi menghasilkan kolagen yang lebih $\underline{\text { tinggi. }}$

Kata kunci: Ekstrasi Kolagen, Asam Klorida, Ikan Tuna.

\section{PENDAHULUAN}

Indonesia adalah negara yang mempunyai wilayah perairan laut dan perairan darat yang sangat luas dibandingkan negara Asean lainnya. Potensi sumber daya alam ini salah satunya menghasilkan ikan dan hasil perikanan yang melimpah. Oleh karenanya, akhir-akhir ini pemerintah sangat mengintensifkan usaha penangkapan, budidaya dan pengolahan ikan (Junianto, 2003).

Limbah perikanan yang dihasilkan diantaranya adalah isi perut, kepala, sirip, kulit, duri dan tulang. Limbah berupa tulang dan kulit ikan merupakan limbah terbesar yang jumlahnya sekitar $20 \%$ dari total berat badan ikan yang berpotensi diproduksi menjadi kolagen. Limbah kulit dan tulang ikan tuna ini belum termanfaatkan secara optimal. Salah satu alternatif untuk optimalisasi pemanfaatan limbah tulang ikan tuna adalah pembuatan kolagen dari tulang ikan tuna yang memiliki nilai ekonomis tinggi (Singkuku, 2017). Kolagen merupakan komponen struktural utama dari jaringan pengikat putih (white connective tissue) yang meliputi hampir $30 \%$ dari total protein pada jaringan organ tubuh vertebrata dan in vertebrata (Setiawati, 2009).

Sebelumnya sumber kolagen menggunakan ekstrak serabut kolagen dari ternak, babi, ayam, mamalia, dan hewan unggas. Namun barubaru ini, penyakit menular pada sapi serta hewan unggas sering terjadi secara terusmenerus, seperti Bovine Spongiform Encephalophaty atau sapi gila, dan flu burung, sehingga keamanan kolagen dari stok hidup dan unggas mengalami masalah keamanan (Herng Wu dan Chai, 2007). Berdasarkan uraian ini peneliti tertarik untuk melakukan penelitian tentang Ekstraksi Kolagen Tulang Ikan Tuna (Thunnus sp) dengan Asam Klorida yang bertujuan menghasilkan bahan aditif alternatif yang dapat diterima seluruh masyarakat. 


\section{MATERIAL DAN METODE}

\section{Bahan dan Alat}

Bahan baku yang digunakan adalah tulang ikan tuna (Thunnus sp). Bahan untuk analisa adalah asamklorida, Aquades.Alat yang digunakanantara lain: Ember, baskom, pisau, telenan, mistar, oven pemanas, kompor. Untuk pengeringan digunakan cabinet dryer. Alat yang digunakan terdiri atas satu unit alat ekstraksi kolagen: toples, beker gelas $1000 \mathrm{ml}$, cool box, saringan dan sentrifuse, kain blacu.

\section{Persiapan sampel}

Tulang ikan tuna dicuci dengan air mengalir untuk membuang sisa sisa daging yang menempel kemudian direbus dengan menggunakan suhu $80^{\circ} \mathrm{C}$ selama kurang lebih $30-1$ jam, setelah itu dikering beberapa menit pada suhu ruang untuk menghilangkan sisasisa air yang ada pada tulang.

Setelah itu ikan dipotong-potong hingga ukuran 1-2 cm. Tulang ikan selanjutnya direndam dalam larutan HCL dengan konsentrasi 1 dan 3\%, dengan perbandingan 1:4 selama 36 jam. Setelah perendaman, tulang akan dicuci dengan air akuades sampai $\mathrm{pH}$ netral maka akan didapatkan ossein. Untuk mendapatkan kolagen maka ossein diekstrak lagi dengan perbandingan 1:3 dengan menggunakan water bath selama 6 jam pada suhu $85^{\circ} \mathrm{C}$ untuk mendapatkan kolagen.

\section{Parameter Uji}

Parameter yang diuji pada penelitian ini adalah rendemen, kadar air dan nilai $\mathrm{pH}$.

\section{Analisa data}

Data hasil penelitian ini dianalisa secara deskriptif yang ditampilkan dalam bentuk histogram atau tabel.

\section{HASIL DAN PEMBAHASAN}

\section{Rendemen}

Perhitungan rendemen kolagen basis kering yaitu dihitung berdasarkan persentase perbandingan berat kering kolagen dengan berat basah bahan baku kulit mentah sebelum ekstraksi. dapat dilihat pada Tabel 1.

Tabel 1. Rendemen kolagen tulang ikan tuna per 500 gram.

\begin{tabular}{ccc}
\hline Konsentrasi HCl $\mathbf{( \% )}$ & Lama Perendaman (Jam) & Rendemen $(\%)$ \\
\hline 1 & 36 & 1,42 \\
\hline
\end{tabular}

Tabel 1 menunjukkan bahwa interaksi perlakuan konsentrasi asam klorida 1\% dan 3\% pada waktu ekstrasi yang ditentukan yaitu selama 36 jam berpengaruh meningkatkan produksi rendemen kolagen secara signifikans. Dimana rendemen yang diperoleh dari pengolahan kolagen merupakan salah satu parameter penting dalam menilai tingkat efektivitas produksi kolagen yang melalui beberapa tahap seperti pemotongan kulit ikan, demineralisasi, hidrolisis dan ekstraksi hingga proses pengeringan.

Semakin tinggi nilai rendemen suatu perlakuan, maka semakin tinggi tingkat efektifitas perlakuan tersebut (Maulida, 2011). Rendemen kolagen yang diperoleh pada ekstraksi asam konsentrasi perendaman asam klorida $1 \%$ dan 3\% berturut-turut adalah 1,42\% dan 5,65\%.

Rendemen yang diperoleh tergolong kecil diakibatkan banyaknya kolagen yang terbuang pada saat proses pencucian mengakibatkan hilangnya massa kolagen dan kemungkinan juga diakibatkan dari proses hidrolisis dan ekstraksi yang kurang sempurna. Menurut Naro, A.B et al. (2013) menyatakan bahwa rendemen, karakter, dan komposisi molekul kolagen sangat dipengaruhi oleh perbedaan spesies, habitat dan perlakuan pada proses ekstraksi.

Singkuku et al., (2017) mengatakan bahwa nilai rendemen gelatin tulang ikan cakalang meningkat tajam, bersamaan dengan meningkatnya konsentrasi $\mathrm{HCl}$. Pada konsentrasi $5 \% \mathrm{HCl}$, kolagen dari tulang ikan cakalang terhidrolisis sempurna menjadi gelatin. Sebaliknya perendaman tulang ikan cakalang dengan $1 \% \mathrm{HCl}$, kolagennya tidak terhidrolisis dengan baik atau sempurna. 


\section{Kadar Air}

Hasil analisa kadar air pada kolagen hasil ekstrasi tulang ikan tuna (Thunnus sp) menggunakan larutan asam klorida dapat dilihat pada Tabel 2.

Tabel 2. Hasil analisa kadar air pada kolagen hasil ekstrasi tulang ikan tuna (Thunnus sp) menggunakan larutan asam klorida.

\begin{tabular}{cccc}
\hline Konsentrasi HCL (\%) & Lama Perendaman (Jam) & Kadar Air (\%) & 7 \\
1 & 36 & 36 & 12 \\
\hline
\end{tabular}

Hasil uji menunjukkan bahwa interaksi perlakuan konsentrasi asam klorida $1 \%$ dan 3\% pada waktu ekstrasi yang ditentukan yaitu selama 36 jam menunjukkan hasil kadar air yang berbeda yaitu $7 \%$ dan $12 \%$. Namun diketahui bahwa kadar air pada kolagen dari tulang ikan tuna yang dihasilkan masih sangat memenuhi standar jika dibandingkan dengan persyaratan mutu kolagen yang telah ditetapkan oleh BSN (2014), yaitu $\leq 12 \%$.

Jaswir et al. (2011) mengatakan bahwa kadar air kolagen dari tulang ikan nila lebih rendah dibandingkan kadar air kolagen dari kulit dan sisik ikan nila. Penyebab rendahnya kadar air kolagen dari tulang adalah struktur kolagen pada tulang lebih kuat dan rapat, sehingga penggunaan asam pada saat ekstraksi tidak dapat menghidrolisis kolagen. Hidrolisis dapat menyebabkan air terperangkap di dalam kolagen. Air pada kolagen dapat disebabkan oleh adanya penetrasi air ke dalam kolagen melalui ikatan hidrogen atau gaya elektrostatik antara gugus polar. Devi et al. (2017) menjelaskan bahwa hidrolisis kolagen dapat menyebabkan terjadinya rantai-rantai peptida pada kolagen lebih pendek, sehingga menyebabkan penyerapan air.

Berdasarkan tabel di atas, Singkuku et al, (2017) mengatakan bahwa kadar air gelatin tulang ikan cakalang jumlahnya rendah dan masih sangat memenuhi standar yaitu maksimum $16 \%$. Sebab kandungan air pada tulang ikan memang hanya berjumlah kecil, berbeda dengan kandungan air pada daging ikan yang berjumlah banyak yaitu sekitar $70-80 \%$ dari berat ikan. Jumlah kadar air tertinggi yaitu terdapat pada gelatin yang dihasilkan dari ekstraksi dan perendaman tulang ikan cakalang dengan larutan $\mathrm{HCl} 5 \%$.

Nilai Derajat Keasaman (pH)

Hasil analisa derajat keasaman $(\mathrm{pH})$ pada kolagen hasil ekstrasi tulang ikan tuna (Thunnus sp) menggunakan larutan asam klorida dapat dilihat pada Tabel 3.

Tabel 3. Hasil analisa derajat keasaman (pH) pada kolagen hasil ekstrasi tulang ikan tuna (Thunnus sp) menggunakan larutan asam klorida

\begin{tabular}{|c|c|c|}
\hline Konsentrasi HCl (\%) & Lama Perendaman (Jam) & pH (\%) \\
\hline 1 & 36 & 4,30 \\
\hline 3 & 36 & 5,19 \\
\hline
\end{tabular}

Hasil uji menunjukkan bahwa interaksi perlakuan konsentrasi asam klorida $1 \%$ dan $3 \%$ pada waktu ekstrasi yang ditentukan yaitu selama 36 jam menunjukkan nilai derajat keasaman (pH) yang tidak jauh berbeda. Diketahui bahwa kolagen yang dihasilkan memiliki $\mathrm{pH}$ berkisar antara 4,30-5,19 (Tabel 3). Nilai pH tersebut tidak sesuai dengan standar kolagen yang ditetapkan oleh BSN (2014), yaitu berkisar antara 6,5-8. Peng et al. (2004) melaporkan bahwa beberapa merk kolagen untuk kosmetik memiliki $\mathrm{pH}$ berkisar antara 3,8-4,7. Hasil penelitian yang sama juga ditunjukkan oleh Devi et al. (2017), yaitu kolagen kulit ikan patin yang diekstraksi menggunakan asam asetat, memiliki pH asam, yaitu 5,53.

Nilai $\mathrm{pH}$ kolagen yang rendah diduga karena proses netralisasi yang tidak sempurna. Alhana et al. (2015) menyatakan bahwa dalam proses penetralan setelah ekstraksi kolagen menggunakan asam, contohnya $\mathrm{CH}_{3} \mathrm{COOH}$, dapat mempengaruhi $\mathrm{pH}$ akhir kolagen yang dihasilkan. Proses penetralan yang sempurna dapat mengurangi residu asam, sehingga kolagen memiliki $\mathrm{pH}$ mendekati netral. 


\section{KESIMPULAN}

Perlakuan lama waktu ekstraksi 36 jam dengan konsentrasi $\mathrm{HCl}$ 3\% menghasilkan nilai rendemen, kadar air dan $\mathrm{pH}$ paling tinggi yaitu berturut-turut 5,65 gram, 12\% dan 5,19. Hasil ini membuktikan bahwa semakin tinggi konsentrasi asam yang diberikan maka dapat menghasilkan kolagen yang lebih maksimal.

\section{DAFTAR PUSTAKA}

Alhana, Suptijah P, Tarman K. 2015. Ekstraksi dan karakterisasi kolagen dari daging teripang gamma. Jurnal Pengolahan Hasil Perikanan Indonesia. 18(2): 150-161.

AOAC. 2005. Official Method of Analysis (18th ed). Washington DC (US): The Association of Official Analytical Chemist.

BSN. 2014. Kolagen kasar dari sisik ikan- syarat mutu dan pengolahan- SNI 8076-2014. Jakarta (ID): Badan Standarisasi Nasional.

Devi HLNA, Suptijah P, Nurilmala M. 2017. Efektifitas alkali dan asam terhadap mutu kolagen dari kulit ikan patin. Jurnal Pengolahan Hasil Perikanan Indonesia. 20(2): 255-265.

Herng Wu, K., dan Huey-Jine Chai. 2007. Collagen of Fish Scale and Method of Making Thereof. Jurnal Ilmiah Internasional. Keelung City.

Jaswir I, Monsur HA, Salleh HM. 2011. Nano-structural analysis of fish collagen extracts for new process development. Africant Journal of Biotechnology. 10(81): 18847-18854.

Junianto, 2003. Teknik Penanganan Ikan. Jakarta : Penebar Swadaya.

Martin A., J. Swarbrick dan A. Cammarata, 1993. Farmasi Fisika,Edisi III, Penerjemah Yoshita. Jakarta : Universitas Indonesia Press.

Martin, A., Swarbick, J., dan A. Cammarata. 1993. Farmasi Fisik 2. Edisi III. Jakarta: UI Press. Pp. 940-1010, 1162, $1163,1170$.

Maulida, R., 2011. Ekstraksi Gelatin Dari Tulang Ikan Tenggiri dengan Variasi Konsentrasi HCl, Universitas Tanjungpura, Pontianak, (Skripsi).

Naro A.B., Sahubawa L. dan Ekantari N., 2013. Ekstraksi dan Karakterisasi Kolagen dari Kulit Ikan Nila Hitam (Oreochoromis niloticus). Jurnal Tekno Sains. Universitas Gadjah Mada Jurusan Perikanan Fakultas Pertanian. Vol 10. Hal : 172 .

Setiawati, I. H. 2009. Karakterisasi Mutu Fisika Kimia Gelatin Kulit Ikan Kakap Merah (Lutjanus Sp.) Hasil Proses Perlakuan Asam. Program Studi Teknologi Hasil Perikanan FPIK Institut Pertanian Bogor. Bogor.

Singkuku T.F, Onibala H., Agustin T.A. 2017. Ekstraksi Kolagen Tulang Ikan Cakalang (Katsuwonus pelamis L.) Menjadi Gelatin Dengan Asam Klorida. Volume 5(3):163-166. 